UCLA. $12 \cdot 870$

\title{
UNIVERSITY OF CALIFORNIA, LOS ANGELES
}
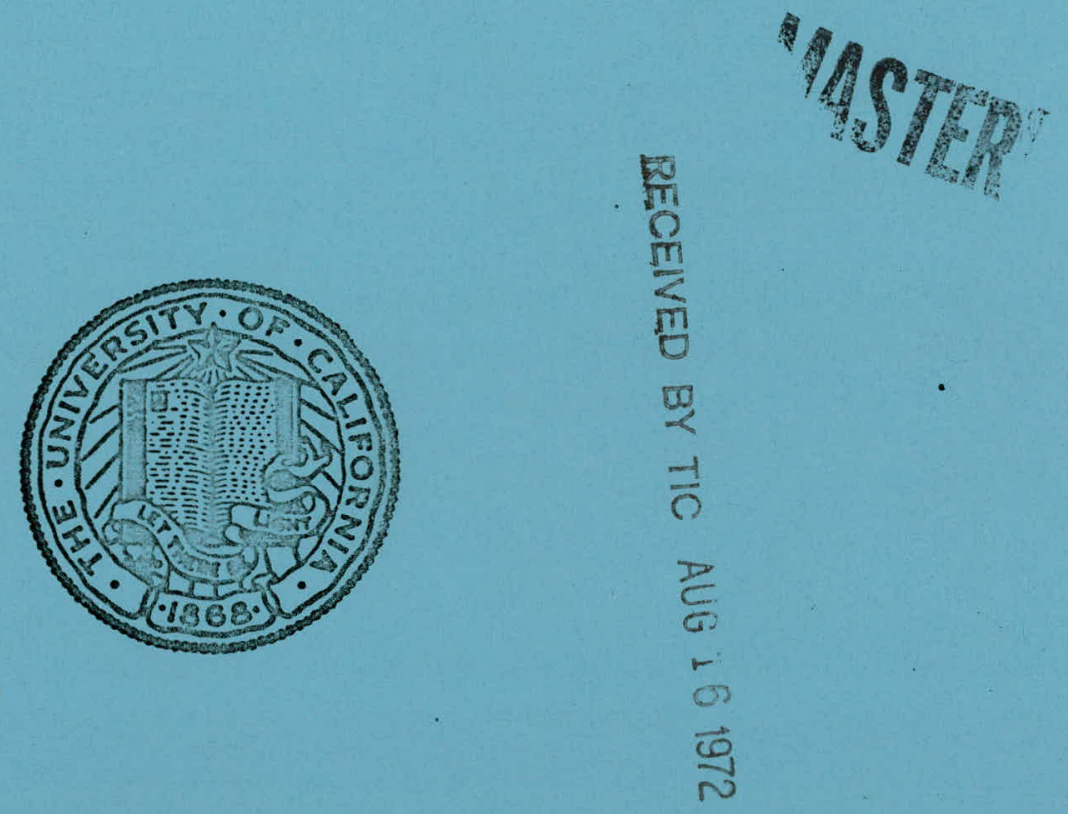

\section{LABORATORY OF NUCLEAR MEDICINE AND RADIATION BIOLOGY CONTRACT NO. AT (04-1) GEN-12}




\section{DISCLAIMER}

This report was prepared as an account of work sponsored by an agency of the United States Government. Neither the United States Government nor any agency Thereof, nor any of their employees, makes any warranty, express or implied, or assumes any legal liability or responsibility for the accuracy, completeness, or usefulness of any information, apparatus, product, or process disclosed, or represents that its use would not infringe privately owned rights. Reference herein to any specific commercial product, process, or service by trade name, trademark, manufacturer, or otherwise does not necessarily constitute or imply its endorsement, recommendation, or favoring by the United States Government or any agency thereof. The views and opinions of authors expressed herein do not necessarily state or reflect those of the United States Government or any agency thereof. 


\section{DISCLAIMER}

Portions of this document may be illegible in electronic image products. Images are produced from the best available original document. 
M. LERNER AND H. HERSCHMAN

IABORATORY OF NUCLEAR MEDICINE AND RADIATION BIOLOGY

900 VETERAN AVENUE

UNIVERSITY OF CALIFORNIA, LOS ANGELES, CALIFORNIA 90024 , NSF GRANT GB-30518 AND NIH POSDOCTORAL FELLOWSHIP 1 FO2

NS . 45571-02

Acknowledgement: These studies were supported in part by the Department of Blological Chemistry and by Contract AT (04-1) GEN-12 between the Atomic Energy Commission and the University of California

\footnotetext{
This report was prepared as an account of work sponsored by the United States Government. Neither the United States nor the United States Atomic Energy Commission, nor any of their employees, nor any of their contractors, subcontractors, or their employees, makes any warranty, express or implied, or assumes any legal liability or responsibility for the accuracy, completeness or usefulness of any information, apparatis, product or process disclosed, or represents that its use would not infringe privately owned rights.
} 
M. Lerner page 1

S-100. Protein Synthesis by Isolated Rat

Brain Polyribosomes 
M. Lerner : page 2

\section{Abstract}

The radioactive proteins synthesiszed in a cell-free system and released from rat brain polyribosomes were analyzed for the presence of a brain specific protein. Rat liver polysomes were used to demonstrate the organ spectficity of the radioactive product synthesized in vitro. S-100 protein was $0.15 \%$ of the radioactive proteins released from brain polyribosomes. 


\section{Lerner page 3}

s-100 protein, an acidic soluble protein is unique to the nervous system (1). Although its role in neural function is not yet clear, it provides an organ-specific marker to study macromolecular synthesis in in vivo and $\underline{\text { in }}$ vitro neural systems. Early in vivo labeling studies of rat brain suggested that. S-100 has very high rates of synthesis and degradation (2). However, a careful reexamination of $S-100$ protein turnover rates in whole rat brain Indicated that the degradation of this protein in vivo occurs at about the same rate as total soluble protein (3). The degradation rates of $\mathrm{S}-100$ and total protein were also quite similar in clonal lines of glial cells in culture. The differential rate of S-100 synthesis in culture was only a fraction of one percent of total protein synthesis (4). Earlier studies using microsomal or ribosomal preparations from rabbit brain indicated that $15 \%$ of the labeled, released protein could be precipitated with anti-s-100 ant1serum (5). Because of these conflicting reports concerning synthesis and degradation, we decided to reinvestigate $S-100$ synthesis in cell-free preparations using rat brain polysomes. Our results indicate that only a small percentage of the ribosomal released protein is $S-100$ protein.

Brains and livers from Sprague-Dawley rats were removed into ice-cold $0.25 \mathrm{M}$ sucrose $-\mathrm{NH}_{4} \mathrm{Cl}$ buffer $\left(0.1 \mathrm{M} \mathrm{NH}_{4} \mathrm{Cl}, 0.03 \mathrm{M} \mathrm{Tris}=\mathrm{HCl}, \mathrm{pH} 7.4,0.005 \mathrm{M}\right.$ $\mathrm{MgCl}_{2}, 0.005 \mathrm{M} \mathrm{B-ME} \mathrm{(6).} \mathrm{Both} \mathrm{tissues} \mathrm{were} \mathrm{minsed,} \mathrm{rinsed} \mathrm{several} \mathrm{times,}$ and homogenized with 8-10 strokes of a teflon-glass homogenizer. The homogenate was centrifuged for 10 minutes at $27,000 \times \mathrm{g}$. The resulting solution was centrifuged for 90 minutes at $195,000 \times \mathrm{g}$. The supernatant solution from the second centrifugation was passed over a G-25 Sephadex column equilibrated with $\mathrm{NH}_{4} \mathrm{Cl}$ buffer. This High speed Supernatant (HSS) was used as a source of enzymes and t-RNA. To prepare polysomes, the $27,000 \times \mathrm{g}$ pellet was rehomogenized 
and centrifuged. The resulting supernatant solution was combined with the pelleted polysomes from the $195,000 \times \mathrm{g}$ centrifugation. After resuspension the polysome solutions were treated with a mixture of DOC-Tween 40: final concentration was $1.0 \%$ DOC - $1 \%$ Tween for brain, and $1.3 \%$ DOC- $1 \%$ Tween for liver. The detergent treated polysomes were kept at $4^{\circ} \mathrm{C}$ for 10 minutes, and then centrifuged at $27,000 \times \mathrm{g}$ for $10 \mathrm{~min}$. The supernatant solutions were then layered over $0.5 \mathrm{M}-2.0 \mathrm{M}$ discontinuous sucrose gradients (in $\mathrm{NH}_{4} \mathrm{Cl}$ buffer) and centrifuged at $4^{\circ} \mathrm{C}$ for $24 \mathrm{hrs}$ at $130,000 \times \mathrm{g}$. After centrifugation the polysome pellets were rinsed with $0.25 \mathrm{M}$ sucrose $-\mathrm{NH}_{4} \mathrm{Cl}$ buffer, resuspended by light homogenization in the same buffer, and centrifuged at $1,000 \times g$ for 10 minutes. The supernatant polysomes were stored at $-70^{\circ} \mathrm{C}$ until use.

The cell-free protein synthesis reaction $(1.0 \mathrm{ml})$ contained: $100 \mu$ moles $\mathrm{NH}_{4} \mathrm{Cl}, 30 \mu$ moles $\mathrm{Tris}-\mathrm{HCl}, \mathrm{pH} 7.4,5 \mu$ moles $\mathrm{MgCl}_{2}, 5 \mu$ moles $\mathrm{B}-\mathrm{ME}, 1 \mu$ mole ATP, $1 \mu$ mole GTP, $10 \mu$ moles creatine phosphate, 4 enzyme untts creatine phosphokinase (Sigma Chemical Co.), $20 \mathrm{~m} \mu$ moles each of a mixture of 15 amino acids and $20 \mathrm{\mu c}$ each $(7)$ of ${ }^{3} \mathrm{H}$ leucine, ${ }^{3} \mathrm{H}$ lysine, ${ }^{3} \mathrm{H}$ phenylalanine, and $3_{H}$ valine. In addition, each reaction contained $6 \mathrm{OD}_{260}$ units of polyribosomes and $1.2 \mathrm{OD}_{280}$ units of HSS. Reactions were incubated for 60 minutes at $37^{\circ} \mathrm{C}$. After incubation the reactions were chilled to $4^{\circ} \mathrm{C}$ and centrifuged for 2 hours at $280,000 \times \mathrm{g}$. to separate the released proteins from the polyribosomes.

The amount of s-100 released from polyribosomes was determined by a modification of the method of Herschman (4). Suitable aliquots of released protein were passed over Sephadex G-15 columns (equilibrated in PBS - $0.01 \mathrm{M}$ $\mathrm{B}-\mathrm{ME}$ ) to remove unincorporated amino acids and $\mathrm{NH}_{4} \mathrm{Cl}$. The excluded volume, 


\section{Lerner page 5}

as determined by dextran ..blue, was concentrated to $2.0 \mathrm{ml}$. with a Diaflow UM-2 membrane (MW exclusion - 1,000; Amicon Corp). Samples were heated to $60^{\circ} \mathrm{C}$ for 10 minutes, then centrifuged for 10 minutes at $27,000 \mathrm{x}$. The supernatants were passed over Sephadex G-25 in PBS. The antibody precipitation and SDS polyacrylamide gei separation of S-100 protein has been described (4). Gels were cut into $1 \mathrm{~mm}$ slices and counted in a Nuclear-ChIcago Ișocap 300 counter.

A profile of the radioactivity in the polyacrylamide gels of S-100anti S-100 precipitates prepared from the protein released from rat brain and liver polyribosomes is shown in Figure 1. The fastest moving protein in the brain sample contained the labeled S-100 protein. The liver sample also contained a small amount of radioactivity in the fastest migrating peak. This radioactivity probably represents proteins trapped in the antibody-antigen complex, and released during treatment with SDS. The fact that the liver sample did contain some radioactivity in the area of the $5-100$ protein emphasizes the importance of using non-neural tissues as controls. The radioactive profile of brain polyribosomal proteins preciptated with anti-S-100 antibody is quite similar to those obtained from rat glial tissue culture cells (4).

Table 1 shows the results of two experiments designed to measure polyribosomal released S-100 protein. Both experiments started with $5-10 \mathrm{ml}$ of polyribosomal released protein containing about 800,000 CPM. After Sephadex G-15 chromatography and Diaflow concentration, there were about 300,000 CPM per sample. Heating the samples to $60^{\circ} \mathrm{C}$ removed about one-third of the brain protein and two-thirds of the liver protein. $s-100$ protein, in the presence of $B-M E$, is not denatured by the heat step. In these experiments 
$0.15 \%$ of the polysomal released protein $s-100$.

In whole rat brain S-100 reaches adult levels by 25 days of age (8). Using complement fixation we have found that in ad:11 rats about $0.5-0.8 \%$ of the soluble protein of brain is $5-100$ protein. A relatively low rate of S-100 synthesis is suggested by the amount of this protein present in rat brain and the modest degradation rate recently reported (3). Unlike previous reports which proposed that a large percentage of brain polyribosomal synthesized protein is $S-100$ (5), our data indicates that S-100 synthesis comprises only a small percentage of the total released protein synthesized on rat brain polyribosomes.

Michael $P$. Lerner

Harvey. R. Herschman

Department of Biological Chemistry and

The Laboratory of Nuclear Medicine and Radiation Biology

UCLA School of Medicine

Los Angeles, California 90024 


\section{References and Notes}

1. B.W. Moore, Biochem. Blophys. Res. Commun. 19, 739 (1965).

2. B.S. McEwen and H. Hyden, J. Neurochem. 13823 (1966).

3. T.J. Cicero and B.W. Moore, Science 169, 1333 (1970).

4. H. R. Herschman, J. Biol. Chem. 246, 7569 (1971).

5. A. L. Rubin and K. H. Stenze1, Proc. Nat. Acad. Sci., U.S. 53, 963 (1965).

6. The abbreviations used are: B-ME, B-mercaptoethanol; HSS, High Speed Supernatant; DOC, sodium deoxycholate; PBS, phosphate buffered saline;

$0.15 \mathrm{Nacl}, 0.01 \mathrm{M} \mathrm{PO}_{4}, \mathrm{pH} 7.0$; SDS, sodium lauryl sulfate; CPM, counts per minute; S.A., Specific activity.

7. The tritiated amino acids, obtained from Schwarz Bioresearch were:

$\left(4,5-{ }^{3} \mathrm{H}\right)$ leucine, S.A., $51 \mathrm{c} / \mathrm{m}$ mole; $\left(2,3-{ }^{3} \mathrm{H}\right)$ lysine, S.A., $42 \mathrm{c} / \mathrm{m}$ mole;

$\left(2,3-{ }^{3} \mathrm{H}\right)$ valine, S.A. $17 \mathrm{c} / \mathrm{m}$ mole; $\left({ }^{3} \mathrm{H}\right)$ phenylalanine, S.A., $6.5 \mathrm{c} / \mathrm{m}$ mole.

8. H. R. Herschman, L. Levine, and J. de Vellis, J. Neurochem. 18629 (1971).

9. R. Mans and G.D. Nove11i, Arch. Biochem. Biophys. 9448 (1961).

10. C. Zomzely-Neurath and C. York, in Abs. Third Meeting Am. Soc. Neurochem.,1972 have also reported the synthesis of $s-100$ using rat brain polysomes.

11. Supported by NSF grant GB-30518 and in part by contract AT (04-1) GEN 12 between the U.S. Atomic Energy Commission and the University of California. MPL was supported in part by NIH postdoctoral fellowship 1 F02 NS 45571-02. 


\section{Lerner page 8}

Table 1. S-100 in rat brain and liver polysome released protein. Polyribosomes were isolated from 35 day old animals, and the amount of S-100 was determined as described in the text. The radioactivity in proteins was determined by the method of Mans and Novelli (9). Counting efficiencies ranged between $33-40 \%$ for all samples.

\section{Sample}

Polysome-free supernatant

After Sephadex G-15

After Diaflow Concentration

After heating and centrifuging

After Sephadex G-25

S-100 gel fractions

Brain Specific $S-100$

(Brain CPM-Liver CPM)

\section{Experiment 1-CPM Experiment 2-CPM}

\begin{tabular}{rrrr} 
Brain & Liver & Brain & \multicolumn{1}{l}{ Liver } \\
840,000 & 860,000 & 700,000 & 680,000 \\
595,000 & 580,000 & 560,000 & 540,000 \\
350,000 & 350,000 & 325,000 & 300,000 \\
220,000 & 95,000 & 250,000 & 100,000 \\
215,000 & 95,000 & 220,000 & 100,000 \\
1,890 & 600 & 1,170 & 130 \\
1,290 & $\ldots$ & 1,040 & --
\end{tabular}

Percent $s-100\left(\frac{C P M ~ S-100}{C P M}\right.$ polysome-free supernatan $\left.t\right)$

0.15

$-$

0.15

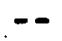


M. Lerner page 9

Flgure Legend

Fig. 1. Polyacrylamide gel patterns of $5-100$ anti-S-100 precipitates prepared from proteins released from rat brain and liver polyribosomes. The proteins released from polyribosomes from 35 day old animals were analysed as described in the text and as shown in Experiment 1, Table 1. The solublized antigen-antibody precipitates were applied at slice number 1. S1ices 23-32 contain S-100 protein as determined by Comassie brilliant blue staining. Open circles, brain; solid circles, liver. 
$300^{\prime}$

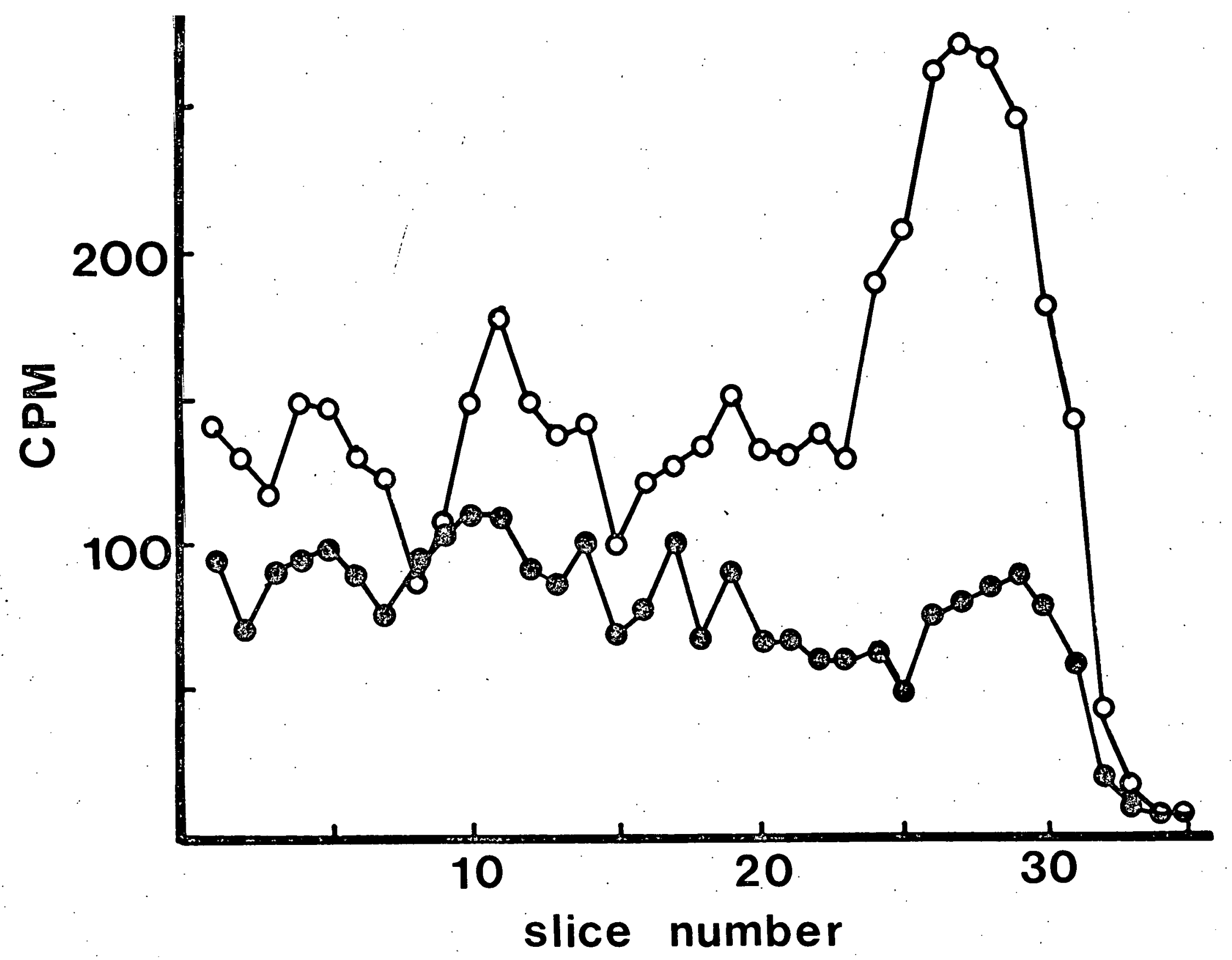


$\bullet$

$\omega$ 